\title{
Response of Container-grown Nursery Plants to Chlorine Used to Disinfest Irrigation Water
}

\author{
Diane Feliciano Cayanan, Mike Dixon, and Youbin Zheng ${ }^{1}$ \\ Controlled Environment Systems Research Facility, Department of \\ Environmental Biology, University of Guelph, 50 Stone Road West, \\ Guelph, Ontario, N1G 2W1, Canada
}

Jennifer Llewellyn
Ontario Ministry of Agriculture, Food and Rural Affairs, Bovey Building,
University of Guelph, 50 Stone Road East, Guelph, Ontario, N1G 2 W1,
Canada

Additional index words. chlorine phytotoxicity, herbaceous shrubs, deciduous shrubs, plant pathogens

\begin{abstract}
The recycling of irrigation water may cause the dispersal of plant pathogens. Irrigation water disinfected with $2.4 \mathrm{mg} \cdot \mathrm{L}^{-1}$ of free chlorine for 5 min was overheadapplied to 17 container-grown nursery plants for 11 weeks in a commercial nursery to evaluate the response of container-grown nursery plants to chlorine. No visual symptoms of injury or growth reduction were observed on the evergreen shrubs (Juniperus horizontalis, Thuja occidentalis, Buxus microphylla, Picea glauca, Rhododendron catawbiense, Taxus media, and Chamaecyparis pisifera), but there were visual injuries and/or growth reduction on some of the deciduous shrubs (Salix integra, Hydrangea paniculata, Prunus $\times$ cistena, Weigela florida, Physocarpus opulifolius). Symptoms of anthracnose were reduced on Cornus alba plants treated with chlorinated water. The chlorine treatment did not affect leaf chlorophyll content. The chlorine treatment killed all fungi and oomycetes in the irrigation water (DNA multiscan). Although there were visible leaf injuries and growth reduction on some of the deciduous plants, chlorine injury did not render them unsalable. Results suggest that irrigation water treated with $2.4 \mathrm{mg} \cdot \mathrm{L}^{-1}$ free chlorine for $5 \mathrm{~min}$ will effectively control the dispersal of common plant pathogens without reducing the market value of container-grown plants.
\end{abstract}

Some nurseries and greenhouses have implemented the recovery and reuse of irrigation water to reduce water consumption and mitigate the potential release of fertilizers and pesticides into the environment (Bush et al., 2003; Hong and Moorman, 2005; Hong et al., 2003). This practice generally involves collecting excess irrigation water and leachate in a reservoir such as a pond for subsequent irrigation. However, recycling of the water may disperse plant pathogens into crops through the irrigation

Received for publication 8 May 2008. Accepted for publication 23 Oct. 2008.

This project was funded by the Canada-Ontario Research and Development Program through Flowers Canada (Ontario) and Landscape Ontario. We appreciate advice provided by Calvin Chong during this study. We thank Tom Intven at Canadale Nurseries Ltd. for providing the experimental site, facilities, and plants for our research. We thank Ian Stewart and Mike Matesic of ClearTech for their assistance in designing the chlorination system and providing the chlorine analyzer and Shane Good, Rick Graham, Robb Parmeter, Ping Zhang, Matt Hannaburg, and the other personnel in our laboratory for their excellent technical support. ${ }^{1}$ To whom reprint requests should be addressed; e-mail yzheng@uoguelph.ca. system (Bush et al., 2003; Hong and Moorman, 2005; Newman, 2004).

Evidence demonstrates that contaminated irrigation water is one of the principal sources of inoculum of Phytophthora and Pythium pathogens in numerous crops (Hong and Moorman, 2005). In the United States alone, crop losses attributed to phytophthora diseases can exceed several billion dollars annually and the worldwide cost for chemical management of phytophthora diseases can represent over $25 \%$ of the annual fungicide market (Kuhajek et al., 2003). In several studies, recycled irrigation water was found to harbor substantial densities of pathogen propagules (Bush et al., 2003; Wangsomboondee and Ristaino, 2002), and disease was more severe when plants were irrigated with contaminated water (Grech and Rijkenberg, 1992; Klotz et al., 1959; McIntosh, 1966; Whiteside and Oswalt, 1973). Hong and Moorman (2005) reported 17 Phytophthora sp., 26 Pythium sp., 27 genera of fungi, eight species of bacteria, 10 viruses, and 13 species of plant parasitic nematodes in ponds, rivers, canals, streams, lakes, runoff water, watersheds, reservoirs, wells, holding tanks, effluents, ebb and flow, recirculating and hydroponic systems. Seven Phytophthora sp. and several Pythium sp. have been recov- ered from the recycling irrigation system at a perennial container nursery in southwestern Virginia (Bush, 2002; Bush et al., 2003; Hong et al., 2003).

Our previous research found that 2.0 $\mathrm{mg} \cdot \mathrm{L}^{-1}$ of free chlorine can kill Pythium aphanidermatum and Phytophthora cactorum zoospores and Phytophthora infestans sporangia (Cayanan et al., 2008a). Cayanan et al. (2008b) found that a free chlorine concentration less than $2.5 \mathrm{mg} \cdot \mathrm{L}^{-1}$ did not adversely affect the growth or appearance of several species of 1-year-old nursery liners during the late growing season (fall) in a small research setting. Frink and Bugbee (1987) and Brown (1991) reported on the phytotoxic effects of chlorine on several greenhouse crops and their free chlorine thresholds, which ranged from $2 \mathrm{mg} \cdot \mathrm{L}^{-1}$ to $77 \mathrm{mg} \cdot \mathrm{L}^{-1}$. However, there is no known published information regarding the use of chlorinated irrigation water under typical nursery practices.

The objective of the present study was to determine whether a free chlorine concentration of $2.4 \mathrm{mg} \cdot \mathrm{L}^{-1}$ would harm common containergrown nursery plants when applied under commercial nursery practices during the period of shoot emergence and growth and whether such a treatment would minimize the dispersal of common plant pathogens in recycled irrigation water.

\section{Materials and Methods}

Plant material and treatments. The experiment was conducted at Canadale Nurseries Ltd. (St. Thomas, Ontario, Canada) from 7 June 2007 to 22 Aug. 2007. Seventeen 1year-old container-grown nursery plant species (Table 1) were tested. All plants were obtained from Canadale Nurseries Ltd. except for the Rhododendron, which were obtained from Blue Sky Nursery Ltd. (Beamsville, Ontario, Canada). Before the experiment, all the plants were grown in hoop houses over winter and in the early spring. Plants were grown in 9.1-L containers except Syringa (4.5 L) and the Juniperus, Thuja, Picea, Taxus, Chamaecyparis, Rhododendron, and Euonymus (13.6 L). The container substrate (Gro-Bark Co., Georgetown, Ontario, Canada) contained composted pine bark, sphagnum peatmoss, coarse perlite, and composted leaf, yard, vegetable, and wood waste amended with surfactant, micronutrient mix, and dolomitic limestone. Container substrate was amended by incorporating $15 \mathrm{~N}-3.9 \mathrm{P}$ $10 \mathrm{~K}$ resin-coated, controlled-release fertilizer at the rate of $1 \mathrm{~kg} \cdot \mathrm{m}^{-3}$ (Osmocote Plus 15-9-12, 5-6 month $21{ }^{\circ} \mathrm{C}$; Scotts Co., Marysville, $\mathrm{OH}$ ). Plants of each species were uniform in height at the beginning of the experiment.

There were two irrigation treatments: (1) nonchlorinated water and (2) chlorinated water. Plants of all species were laid out in a completely randomized split block design with four blocks and two treatments. Five plants of each species in each block were grouped together as one experimental unit 
Table 1. Plant species used to test the effects of chlorinated irrigation water on spray-irrigated, containergrown shrubs.

\begin{tabular}{|c|c|c|c|}
\hline Plant type & Plant species & Common name & Cultivar name \\
\hline \multirow[t]{10}{*}{ Deciduous } & Cornus alba & Ivory halo dwarf silver dogwood & Bailho \\
\hline & Euonymus fortunei & Emerald gaiety euonymus & Emerald Gaiety \\
\hline & Hydrangea paniculata & Peegee hydrangea & Grandiflora \\
\hline & Physocarpus opulifolius & Coppertina ninebark & Coppertina \\
\hline & Prunus $\times$ cistena & Purpleleaf sandcherry & Not available \\
\hline & Salix integra & Japanese variegated willow & Alba Maculata \\
\hline & Spiraea japonica & Goldmound spirea & Goldmound \\
\hline & Syringa meyeri & Dwarf Korean lilac & Palibin \\
\hline & Viburnum $\times$ carlcephalum & Fragrant viburnum & Not available \\
\hline & Weigela florida & Fine wine weigela & Not available \\
\hline \multirow[t]{7}{*}{ Evergreen } & Buxus microphylla & Green velvet boxwood & Green Velvet \\
\hline & Chamaecyparis pisifera & Sungold threadleaf cypress & Filifera \\
\hline & Juniperus horizontalis & Limeglow $^{\text {TM }}$ golden juniper & Not available \\
\hline & Picea glauca & Dwarf Alberta spruce & Conica \\
\hline & Rhododendron catawbiense & Rhododendron & Album \\
\hline & Taxus media & Hick's yew & Hicksi \\
\hline & Thuja occidentalis & Emerald cedar & Smaragd \\
\hline
\end{tabular}

with each plant as a subsample. Plants were overhead-irrigated with impact spray emitters (Rittenhouse, Niagara, Ontario, Canada). The spray application rate was $46.2 \mathrm{~L} \cdot \mathrm{min}^{-1}$ over an area of $63.6 \mathrm{~m}^{2}$. Plants were watered for $30 \mathrm{~min}$ three times a day (at $0500 \mathrm{HR}, 0700$ $\mathrm{HR}$, and $0900 \mathrm{HR}$ ) for 11 weeks. Each day, the 4.5-, 9.1-, and 13.6-L containers received a total volume of 227,300 , and $391 \mathrm{~mL}$ of water, respectively.

All water used for irrigation was taken directly from the collection pond. The free chlorine concentration of the nonchlorinated water was measured weekly and had an average free chlorine concentration of 0.16 with a SD of $\pm 0.03 \mathrm{mg} \cdot \mathrm{L}^{-1}$. Pond water was disinfected using a chlorination system from ClearTech (ClearTech, Mississauga, Ontario, Canada), which pumped pond water from the collection pond into a 1386-L mixing tank. A chlorine stock solution of $12,500 \mathrm{mg} \cdot \mathrm{L}^{-1}$ was injected into the tank and mixed until the free chlorine concentration of the water was 2.4 $\mathrm{mg} \cdot \mathrm{L}^{-1}$ and was held at this concentration for 5 min before plants were overhead-irrigated. The chlorine stock solution was prepared with $5.25 \%$ sodium hypochlorite (Javex Bleach; Colgate-Palmolive Canada Inc., Toronto, Ontario, Canada) and well water. The free chlorine concentration of the well water averaged $0.03 \pm 0.01 \mathrm{mg} \cdot \mathrm{L}^{-1}$. The $\mathrm{pH}$ of the chlorinated water was adjusted to 6.5 to 7.0 with 5\% acetic acid (Pure White Vinegar; Loblaw Inc., Toronto, Ontario, Canada) because chlorine is reported to be the most effective at this $\mathrm{pH}$ range (Frink and Bugbee, 1987). A 9184sc Amperometric Free Chlorine Sensor (Hach Co., Loveland, CO) was used to measure the free chlorine concentration inside the mixing tank and a C201 Oakton Colorimeter (Oakton Instruments, Vermont Hills, IL) was used to measure the free chlorine concentration of the irrigation water collected at the impact spray emitter. As a result of the short distance between the mixing tank and the spray emitter, no chlorine concentration difference was detected during the experiment.

A free chlorine concentration of 2.4 $\mathrm{mg} \cdot \mathrm{L}^{-1}$ and a contact time of $5 \mathrm{~min}$ was chosen based on our previous research, which indicated that a free chlorine concentration less than $2.5 \mathrm{mg} \cdot \mathrm{L}^{-1}$ should not have any adverse effect on the growth or appearance of most plants (Cayanan et al., 2008b), but 2.0 $\mathrm{mg} \cdot \mathrm{L}^{-1}$ or greater of free chlorine with a minimum contact time of $3.0 \mathrm{~min}$ should kill the common plant pathogens $P$. aphanidermatum, $P$. cactorum, and $P$. infestans (Cayanan et al., 2008a).

Samples and measurements. Visual injury of plant leaves, detected by the unaided eye, was expressed as the percentage of leaves or flowers on the plant exhibiting the visual injury (i.e., flower necrosis, marginal necrosis, chlorosis, curling, and loss of leaves) on the whole plant. Plants were rated once a week for 11 weeks.

On 23 Aug. 2007, after 11 weeks of growth, three plants from each experimental unit were randomly selected for growth and physiological measurements. Plant height was measured from the substrate surface and canopy spread was the average of two perpendicular measurements. Leaf chlorophyll content index (CCI) of the youngest fully expanded leaf without visible injury was determined using a CCM-200 (OptiSciences, Tyngsboro, MA). Plant shoots were divided into stems and leaves. Leaf area (LA) was measured using a leaf area meter (LI3100; LI-COR, Lincoln, NE). Plant tissues were dried at $60{ }^{\circ} \mathrm{C}$. Specific leaf area (SLA) was calculated by dividing LA by leaf dry weight. Leaf area, leaf and stem dry weight, SLA and CCI were not determined for Chamaecyparis, Juniperus, Thuja, Taxus, and Picea.

Rhododendron, Hydrangea, and Syringa were further analyzed to represent the three sizes of containers $(13.6,9.1$, and $4.5 \mathrm{~L}$, respectively) used to grow the plants. At harvest, leachate was collected from the containers of harvested plants using the pourthrough method as described by Wright (1986) and analyzed for chloride $\left(\mathrm{Cl}^{-}\right)$using high-performance liquid chromatography (HPLC), DX500 (DIONEX, Oakville, Ontario, Canada) as described by Zheng et al. (2004). In addition, the amount of free chlorine input (mg) per kilogram of growing substrate was calculated in this study as follows:

Free chlorine input $=\left(\mathrm{V}_{\mathrm{w}} / \mathrm{t} / \mathrm{Cl}\right) / \mathrm{m}$

where $V_{w}$ is the average volume of irrigation water applied daily $\left(\mathrm{L} \cdot \mathrm{d}^{-1}\right), \mathrm{t}$ is the length of the experiment (day), $\mathrm{Cl}$ is the average free chlorine concentration of the irrigation water $\left(\mathrm{mg} \cdot \mathrm{L}^{-1}\right)$, and $\mathrm{m}$ is the mass of the substrate $(\mathrm{kg})$. The mass of the substrate was measured by drying the growing substrate under $105^{\circ} \mathrm{C}$ until the weight was constant.

Samples of nonchlorinated and chlorinated irrigation water were collected on Day 6 and Day 71 for detection of plant pathogens using DNA multiscan analysis (University of Guelph Laboratory Services Pest Diagnostic Clinic). Water samples (three samples for both chlorinated and nonchlorinated water at each time) were stored in a cooler with ice and submitted for testing $2 \mathrm{~h}$ after sample collection. In the tests, membrane-type "fungi and oomycetes" was used to analyze irrigation water samples collected on Day 6 and membrane type "G" on Day 71. Both membrane types detect common species of Pythium and Phytophthora, including the pathogens $P$. aphanidermatum, $P$. cactorum, and $P$. infestans.

Statistical analysis. All data were tested for normality and homogeneity before analysis of variance with SAS software Version 9.1 (SAS Institute, Cary, NC). Contrast comparisons using a Type I error rate of 0.05 were used to determine the chlorine effects on each plant species.

\section{Results}

Visual injury. None of the evergreen shrubs (Juniperus, Thuja, Buxus, Picea, Rhododendron, Taxus, and Chamaecyparis) exhibited visual injury caused by chlorine; visual injuries were observed on five of the 10 deciduous shrubs tested.

No visual injury was observed on deciduous shrubs from Day 1 to 56. On Day 57, 5\% of the juvenile leaves on Salix displayed marginal necrosis as a dark brown color. Five percent of the mature leaves on Hydrangea displayed marginal necrosis as a dark brown color. Five percent of flowers on Hydrangea also displayed necrosis as an orange-brown color.

On Day 76, Salix and Hydrangea displayed the same extent of visual injuries as observed on Day 57, but new visual injuries were observed. Ten percent of the juvenile leaves of Salix displayed curling and Hydrangea displayed a $10 \%$ leaf drop compared with the plants treated with nonchlorinated water. Five percent of the leaves of Prunus displayed marginal necrosis as a grayish brown color. Fifteen percent of Weigela leaves displayed chlorosis as a light green color and $10 \%$ of the juvenile leaves of Weigela also exhibited curling. Fifteen percent of the leaves of Physocarpus displayed chlorosis as a light yellow color. All Cornus exposed to nonchlorinated water during this experiment 
displayed anthracnose (Discula destructiva), a leaf spot disease. However, there was a $65 \%$ reduction of anthracnose on Cornus treated with chlorinated water.

Growth. The growth of plant species responded differently to the chlorine treatment (Tables 2 and 3). LA, leaf dry weight, stem dry weight, total aboveground dry weight, and height of Salix were reduced by chlorine, but there was no effect on spread and SLA. For Hydrangea, Prunus, Physocarpus, and Euonymus, only LA was reduced, but no treatment effect was observed for the leaf dry weight, stem dry weight, total aboveground dry weight, height, spread, and SLA. The SLA of Cornus treated with the chlorinated water was greater than that of Cornus plants treated with the nonchlorinated water, but no treatment effect was observed for the LA, leaf dry weight, stem dry weight, total aboveground dry weight, height, and spread. None of the growth parameters of the remaining deciduous shrubs (Syringa, Weigela, Spiraea, and Viburnum) and all of the evergreen shrubs (Rhododendron, Buxus, Chamaecyparis, Juniperus, Thuja, Taxus, and Picea) were affected by chlorine.

Leaf chlorophyll content. Chlorine treatment had no effect on the leaf CCI for any of the 17 plant species (Table 3 ).

Free chlorine input and growing substrate. Total free chlorine input during the 11 -week experiment was 9,6 , and $5 \mathrm{mg} \cdot \mathrm{kg}^{-1}$ of substrate in the 4.5-, 9.1-, and 13.6-L containers. HPLC analysis showed no difference in the $\mathrm{Cl}^{-}$content of the nonchlorinated and chlorinated growing substrates. For Rhododendron, Hydrangea, and Syringa, the leachate $\mathrm{Cl}^{-}$concentration measured by the pourthrough method was $321.4 \pm 26.71$, $1724.4 \pm 26.71$, and $330.7 \pm 26.71 \mathrm{mg} \cdot \mathrm{L}^{-1}$, respectively.

DNA multiscan. On Day 6, nonchlorinated water had low levels of Fusarium sp., moderate levels of Phytophthora sp., high levels of Pythium sp., and low levels of Verticillium dahliae. On Day 71, the non- chlorinated water had low levels of Pythium $\mathrm{sp}$. and there was no detection of any fungi or oomycetes in the chlorine treatment on both Days 6 and 71.

\section{Discussion}

In this study, chlorine had no phytotoxic or growth effects on any of the evergreen (broad-leaf or needle-type) shrubs. Visual injuries were observed on several of the deciduous shrubs. Surface wax on the leaves may limit or prevent the retention of irrigation water on the foliage of evergreen shrubs. In contrast, deciduous shrubs have relatively soft, nonwaxy, and hairy leaves, which may allow retention of irrigation water on the plant surface, prolonging exposure of the leaves to any chlorine in the water and potentially resulting in leaf injury. Nonetheless, many of the observed injuries were mild and difficult to detect.

Our previous research (Cayanan et al., 2008 b) indicated that a free chlorine concentration less than $2.5 \mathrm{mg} \cdot \mathrm{L}^{-1}$ did not adversely affect Physocarpus opulifolius, Salix integra, Hydrangea paniculata, Weigela florida, or Spiraea japonica. In our present study, the $2.4 \mathrm{mg} \cdot \mathrm{L}^{-1}$ of free chlorine caused visual injury on Weigela florida; caused both visual injury and growth reduction on Physocarpus, Salix integra, and Hydrangea; but Spiraea japonica was unaffected.

Differences in results may be the result of the fact the plants in the previous study were irrigated with chlorinated water long after the new growth had hardened off, whereas in the present study, plants were irrigated between June and August when they were more actively growing. It is worth noting also that injuries appeared after 8 weeks $(56 \mathrm{~d})$ of exposure to chlorinated water in the present study, whereas our previous study was only 6 weeks (42 d) in duration.

Although results of this study show that chlorinated water could be applied for up to 8 weeks, in actual practice, the chlorinated irrigation water need not be applied continuously once plant pathogens are under control. Intermittent exposure to chlorine may reduce the phytotoxic effects that were observed in some species as a result of 8 weeks of continuous chlorine exposure.

Lack of any difference in the $\mathrm{Cl}^{-}$content of the substrate of all three container sizes also suggests that short-term use of 2.4 $\mathrm{mg} \cdot \mathrm{L}^{-1}$ of free chlorine may not result in excess $\mathrm{Cl}^{-}$being released into the environment from leachate. Concurrent laboratory studies found that it required $30,000 \mathrm{mg}$ of free chlorine applied to $1 \mathrm{~kg}$ of growing substrate (same substrate used in the current study) to establish a detectable chlorine residual (chlorine not consumed by organic matter; data not shown). After 11 weeks of irrigation with chlorinated water in our study, the total free chlorine input to the growing substrate was 9,6 , and $5 \mathrm{mg}$ per kilogram of growing substrate in the 4.5-, 9.1-, and 13.6-L containers, respectively. These values are considerably less than $30,000 \mathrm{mg}$ of free chlorine per kilogram of growing substrate and would not be enough to establish free chlorine residual. In addition, free chlorine applied to the growing substrate would be oxidized by the organic matter of the growing substrate, which would prevent the establishment of a free chlorine residual.

In agreement with our previous work, Hong et al. (2003) reported that zoospores of Phytophthora sp. may be killed with free chlorine concentrations ranging from 0.25 to $2 \mathrm{mg} \cdot \mathrm{L}^{-1}$. Our previous work also indicated that zoospores of $P$. infestans were killed with $1.0 \mathrm{mg} \cdot \mathrm{L}^{-1}$ of free chlorine with a contact time of $3.0 \mathrm{~min}$; zoospores of $P$. cactorum with $0.3 \mathrm{mg} \cdot \mathrm{L}^{-1}$ and contact time of $6.0 \mathrm{~min}$; and sporangia of $P$. aphanidermatum with $2.0 \mathrm{mg} \cdot \mathrm{L}^{-1}$ and contact time of $3.0 \mathrm{~min}$. These results are in agreement with our DNA multiscan results because all fungi and oomycetes detected in the nonchlorinated water were killed in the chlorinated water in our present study.

Table 2. The leaf area (LA), leaf dry weight, stem dry weight, total aboveground dry weight, height, spread, specific leaf area (SLA), and leaf chlorophyll content of 17 container-grown nursery plant species overhead irrigated with chlorinated water $\left(2.4 \mathrm{mg} \cdot \mathrm{L}^{-1}\right)$ and nonchlorinated water $\left(0 \mathrm{mg} \cdot \mathrm{L}^{-1}\right)$.

\begin{tabular}{|c|c|c|c|c|c|c|c|c|}
\hline Plant species & LA $\left(\mathrm{cm}^{2}\right)$ & $\begin{array}{l}\text { Leaf dry wt } \\
\text { (g) }\end{array}$ & $\begin{array}{l}\text { Stem dry wt } \\
\text { (g) }\end{array}$ & $\begin{array}{l}\text { Total aboveground } \\
\text { dry wt (g) }\end{array}$ & $\begin{array}{l}\mathrm{Ht} \\
(\mathrm{cm})\end{array}$ & $\begin{array}{l}\text { Spread } \\
(\mathrm{cm})\end{array}$ & $\begin{array}{l}\text { SLA } \\
\left(\mathrm{cm}^{-2} \cdot \mathrm{g}\right)\end{array}$ & $\begin{array}{l}\text { Chlorophyll } \\
\text { (CCI) }\end{array}$ \\
\hline Salix integra & $8,416 * * *$ & $62.6^{*}$ & $116.9 *$ & $179.5^{*}$ & $114 *$ & 142 & 146 & 15 \\
\hline Hydrangea paniculata & $4,541^{*}$ & 22.9 & 18.9 & 41.8 & 57 & 66 & 164 & 32 \\
\hline Syringa meyeri & 81 & 1.5 & 1.4 & 2.9 & 19 & 13 & 54 & 16 \\
\hline Weigela florida & 1,449 & 11.5 & 5.5 & 17.0 & 41 & 389 & 126 & 30 \\
\hline Spiraea japonica & 3,388 & 17.0 & 8.7 & 25.7 & 27 & 41 & 199 & 7 \\
\hline Euonymus fortunei & 1,331 & 24.2 & 11.7 & 35.9 & 31 & 35 & 55 & 73 \\
\hline Rhododendron catawbiense & $6,494 *$ & 61.1 & 71.4 & 132.5 & 44 & 51 & 104 & 103 \\
\hline Buxus microphylla & 6,133 & 106.6 & 72.7 & 179.3 & 36 & 43 & 58 & 107 \\
\hline Chamaecyparis pisifera & ND & ND & ND & 125.7 & 33 & 42 & ND & ND \\
\hline Juniperus horizontalis & ND & ND & ND & 60.3 & 28 & 31 & ND & ND \\
\hline Thuja occidentalis & ND & ND & ND & 282.7 & 57 & 38 & ND & ND \\
\hline Taxus media & ND & ND & ND & 35.3 & 31 & 20 & ND & ND \\
\hline
\end{tabular}

$\mathrm{ND}, *, * * *$ Not determined, chlorine treatment effect significant at $P<0.05$ and $P<0.0001$, respectively.

Values with $*$ and $* * *$ are the mean of the nonchlorinated treatment. All of the others are the mean of the nonchlorinated and chlorinated treatments. 
Table 3. Percent reduction of leaf area (LA), leaf dry weight, stem dry weight, total aboveground dry weight, height, and specific leaf area (SLA) caused by chlorinated irrigation water $\left(2.4 \mathrm{mg} \cdot \mathrm{L}^{-1}\right)$ compared with the nonchlorinated plants on container-grown nursery plant species.

\begin{tabular}{|c|c|c|c|c|c|c|}
\hline \multirow[b]{2}{*}{ Plant species } & \multicolumn{6}{|c|}{ Percent reduction $(\%)$} \\
\hline & LA & Leaf dry wt & Stem dry wt & $\begin{array}{c}\text { Total aboveground } \\
\text { dry wt }\end{array}$ & $\mathrm{Ht}$ & SLA \\
\hline$\overline{\text { Prunus } \times \text { cistena }}$ & 50 & & & & & \\
\hline Salix integra & 44 & 51 & 49 & 50 & 16 & \\
\hline Hydrangea paniculata & 38 & & & & & \\
\hline Physocarpus opulifolius & 15 & & & & & \\
\hline Cornus alba & & & & & & -24 \\
\hline Euonymus fortunei & 8 & & & & & \\
\hline
\end{tabular}

Percentage reductions were presented only when there was a significant treatment effect within the tested species at $P<0.05$ level. Positive numbers represent reduction and negative numbers represent an increase in growth.

We also observed the suppression of a foliar disease, dogwood anthracnose, caused by Discula destructiva (Carr and Banas, 2000; Daughtrey and Hibben, 1994; Dudt and Shure, 1993; Redlin, 1991). It is a serious disease known to cause necrosis (Carr and Banas, 2000; Daughtrey and Hibben, 1994; Redlin, 1991), leaf spot, leaf blotch, blight, dieback (Daughtrey and Hibben, 1994; Redlin, 1991), twig dieback (Redlin, 1991), and defoliation (Daughtrey and Hibben, 1994) in Cornus sp. Cornus in this experiment displayed anthracnose on both the nonchlorinated and chlorinated plants. However, foliar symptoms of anthracnose on Cornus treated with chlorinated water was reduced by $65 \%$ compared with the nonchlorinated Cornus. Also, free chlorine concentration of 2.4 $\mathrm{mg} \cdot \mathrm{L}^{-1}$ did not cause any visual injuries or negative growth effects on the Cornus. To manage dogwood anthracnose, growers are recommended to use best management practices such as reducing leaf wetness periods (Daughtrey and Hibben, 1994). Growers may also use fungicides to manage the disease; however, these methods do not kill the disease inoculum. Moorman and Lease (1999) reported that pruning of Cornus branches infected with anthracnose improved the appearance of the plants but did not eliminate the disease. Pruning is also time-consuming and other labor-intensive efforts managing the disease. The reduction of anthracnose severity with chlorinated water may reduce the number of applications of fungicides.

In conclusion, our research found that 2.4 $\mathrm{mg} \cdot \mathrm{L}^{-1}$ of free chlorine with a contact time of $5.0 \mathrm{~min}$ in the nursery irrigation water killed all fungi and oomycetes and was safe for all seven evergreen shrubs tested. Visual injuries on the deciduous shrubs appeared on only some of the plants and were not considered sufficient to render them unsalable. We also determined that the amount of chlorine used to chlorinate $1000 \mathrm{~L}$ of irrigation water with a free chlorine concentration of $2.4 \mathrm{mg} \cdot \mathrm{L}^{-1}$ is $494.4 \mathrm{~mL}$ of $5 \%$ bleach, which currently costs $\$ 0.23$ U.S. This research provides new information for developing economic water treatment systems to reduce the dispersal of common plant pathogens without affecting the market value of plants.

\section{Literature Cited}

Brown, D. 1991. Effect of irrigating flowering plants and turf grass with chlorinated water. Ontario Hydro Research Division Report K. 91-73, Ontario, Canada.

Bush, E.A. 2002. Characterization of Phytophthora species in recycled irrigation water at a container nursery in southwestern Virginia. VA Polytechnic Inst. State Univ, VA, MSc Diss.

Bush, E.A., C. Hong, and E.L. Stromberg. 2003. Fluctuations of Phytophthora and Pythium spp. in components of a recycling irrigation system. Plant Dis. 87:1500-1506.

Carr, D.E. and L.E. Banas. 2000. Dogwood anthracnose (Discula destructiva): Effects of and consequences for host (Cornus florida) demography. Amer. Midl. Nat. 143:169-177.

Cayanan, D., P. Zhang, W. Liu, M. Dixon, and Y. Zheng. 2008a. Efficacy of using chlorine in controlling five common plant diseases in irrigation water. HortScience 44: $x x x-x x x$.

Cayanan, D.F., Y. Zheng, C. Chong, P. Zhang, T. Graham, J. Llewellyn, and M. Dixon. 2008b. Sensitivity of five container-grown nursery species to chlorine in overhead irrigation water. HortScience 43:1882-1887.

Daughtrey, M.L. and C.R. Hibben. 1994. Dogwood anthracnose: A new disease threatens two native Cornus species. Annu. Rev. Phytopathol. 32:61-73.

Dudt, J.F. and D.J. Shure. 1993. The effect of anthracnose (Discula destructiva) infection on plant-herbivore interactions in dogwood (Cornus florida). Oecologia 96:108-113.

Frink, C.R. and G.J. Bugbee. 1987. Response of potted plants and vegetable seedlings to chlorinated water. HortScience 22:581-583.

Grech, N.M. and F.H.J. Rijkenberg. 1992. Injection of electrolytically generated chlorine into citrus microirrigation systems for the control of certain waterborne root pathogens. Plant Dis. 76:457-461.

Hong, C.X. and G.W. Moorman. 2005. Plant pathogens in irrigation water: Challenges and opportunities. Crit. Rev. Plant Sci. 24:189208.

Hong, C.X., P.A. Richardson, P. Kong, and E.A. Bush. 2003. Efficacy of chlorine on multiple species of Phytophthora in recycled nursery irrigation water. Plant Dis. 87:11831189.

Klotz, L.J., P.P. Wong, and T.A. DeWolfe. 1959. Survey of irrigation water for the presence of Phytophthora spp. pathogenic to citrus. Plant Dis. Rptr. 43:832.

Kuhajek, J.M., S.N. Jeffers, M. Slattery, and D.E. Wedge. 2003. A rapid microbioassay for discovery of novel fungicides for Phytophthora spp. Phytopathology 93:46-53.

McIntosh, D.L. 1966. The occurrence of Phytophthora spp. in irrigation systems in British Columbia. Can. J. Bot. 44:1591-1596.

Moorman, G.W. and R.J. Lease. 1999. Effects of pruning in the management of dogwood and pine branch dieback in the landscape. J. Arboric. 25:274-277.

Newman, S.E. 2004. Disinfecting irrigation water for disease management. Society of American Florists 20th Annual Conference on Pest Management on Ornamentals, San Jose, CA, Feb. $20-22$.

Redlin, S.C. 1991. Discula destructiva sp. nov., cause of dogwood anthracnose. Mycologia 83:633-642.

Wangsomboondee, T. and J.B. Ristaino. 2002. Optimization of sample size and DNA extraction methods to improve PCR detection of different propagules of Phytophthora infestans. Plant Dis. 86:247-253.

Whiteside, J.O. and T.W. Oswalt. 1973. An unusual brown rot outbreak in a Florida citrus grover following sprinkler irrigation with Phytophthora-infested water. Plant Dis. Rptr. 57:391-393.

Wright, R.D. 1986. The pour-through nutrient extraction procedure. HortScience 21:227229.

Zheng, Y., T. Graham, S. Richard, and M. Dixon. 2004. Potted gerbera production in a subirrigation system using low-concentration nutrient solutions. HortScience 39:1283-1286. 